\title{
AZ EGÉSZ NAPOS ISKOLAI FOGLALKOZTATÁS PEDAGÓGIAI HASZNOSSÁGÁNAK VIZSGÁLATA A PEDAGÓGUSOK VÉLEMÉNYÉNEK TÜKRÉbEN KOMÁroM-ESZTERgOM, FEJÉr, VESZPRÉM, ZALA ÉS TOLNA MEGYE ÁLTALÁNOS ISKOLÁIBAN
}

\section{Kanczné Nagy Katalin}

Eötvös Loránd Tudományegyetem

\section{A kutatás előzményei}

Az elmúlt évek talán legnagyobb oktatásügyi vitáját az egész napos iskola bevezetésének lehetősége váltotta ki. Szakértőkön és a pedagógusok szakmai és szakszervezetein kívül a szülök körében is heves reakciókat keltett. Ellenérvekkel, ellenérzésekkel, sőt ellenállással fogadták a hírt azok a családok, amelyeknél a családi béke, az otthon melege, szerencsére, természetes állapot, s ahová mindennap a lehető legkorábbi időben várják haza az iskolás csemeté(ke)t.

A koncepciót szkepticizmussal fogadók jogosnak tekinthető kérdéseket vetettek fel. Mi lesz eztán azokkal a különórákkal, ahová a szülök, saját finanszírozással, maguk hordták gyermekeiket? Ezek az órák (tánc, zene, sport stb.) az iskolától távolabb eső intézményekben folynak. Megoldható lesz-e az utaztatás vagy a különórákat az iskola épületében tartják ezután?

Figyelemreméltó felvetés, hogy az egész napos nevelés rendkívül eszközigényes, hiszen sokkal több játékra, fejlesztő, oktató eszközre van szükség ahhoz, hogy a tanulók egész napját értelmesen lehessen megszervezni és sokrétü pedagógiai munkát lehessen megvalósítani. Mindehhez osztályonként két pedagógus szükséges, de a változatos tevékenykedtetés biztosítása érdekében drámapedagógus, fejlesztő pedagógus, edző, tánctanár és egyéb más szakember munkája sem nélkülözhető. Ki fizeti majd az iskolai fejlesztéseket?

Mindemellett, bár a pedagógusok jelentős része dolgozik vagy dolgozott már napközi, illetve iskolaotthonos formában, jelentős azok aránya is, akik számára az egész napos iskoláztatás újszerü lenne. Öket nyilvánvalóan szakmai képzéseken kell majd felkészíteni. Van erre pénz?

Az iskolák működési rendjét át kell alakítani, s az új rendben minden ott dolgozónak meg kell találni a helyét, a feladatát. Honnan kapnak az intézmények ehhez segítséget?

$S$ végül, de nem utolsósorban a lelki tényezőkre gyakorolt hatások is említésre méltóak. A rendszerváltás óta ugyanis az oktatás ügye folyamatos reformokon megy keresztül, melyek a pedagógusokat újabb és újabb készségek és ismeretek elsajátítására, gyakran attitüdváltásokra késztették: a központi tanterv után a kerettanterveknek megfelelő pedagógiai programok készítése, a kompetencia alapú oktatáshoz szükséges szemléletváltás, új metodika elsajátítása, a nem szakrendszerü oktatás rendszerének kialakítása, új informatikai eszközök használatára való felkészülés. Egyes vélemények szerint mindez már túlmutat az 
önképzés egyébként szükséges követelményén, s a pedagógusszakma talajt vesztetté kezd válni. Vajon elbír-e még egy újabb gyökeres változtatást?

Az egész napos iskola koncepciójának támogatói viszont nagyon jó gyakorlatnak tartják, hiszen napjainkban, nagymértékben az anyák munkába állása miatt, egyre növekvő tendencia, hogy a gyermekek naponta hét, nyolc, de akár tíz órát is az iskolában töltenek. Az iskolának mindenkoron alkalmazkodnia kell az aktuális társadalmi igényekhez, s végső soron az a feladata, hogy ezeket maximálisan kielégítse.

Napjainkban a felgyorsuló gazdasági, technikai és tudományos fejlődéssel lépést tartani nagy kihívást jelent minden ember számára. Az erre való felkészítésben óriási felelőssége van az iskolákban folyó oktató-nevelő munkának. Az egész napos iskolai foglalkoztatás egyik célja éppen ebben nyilvánul meg: a tanítási órákon kívüli nevelés nagyon sok olyan lehetőséget biztosít, amelyek során a tanulók sokoldalúan fejlődhetnek tovább. Ehhez a gyermekek tanórai és tanórán kívüli nevelését szerves egységben szükséges megvalósítani. Lehetővé kell tenni, hogy a tanulók megszerzett ismereteiket alkalmazni tudják egyéb területeken is; képességeiknek megfelelően önállóvá tudjanak válni a tanulásban; ismerjenek meg sokféle szabadidős tevékenységet és kulturáltan töltsék el szabadidejüket. Kapják meg azokat az ismereteket, amelyeken keresztül képessé válnak az egészséges életmód szokásainak alkalmazására; kapjanak segítséget a hétköznapi életben való eligazodáshoz, azaz segíteni kell az egyéni szocializációt a közösségi élet szabályainak elsajátításával, ami a hátrányos helyzetü térségekben különös jelentőséggel bír.

A társadalom azon igénye, hogy az iskola gondoskodjon a gyermekekről a tanítási órákon túli időszakban is, több mint százéves. Erről az 1900-as évek elejétől terjedő gyakorlatról így ír az 1976-os „Pedagógiai lexikon”: „Az egész napos nevelés a nevelési folyamat kiterjesztése a dolgozó szülök gyermekei számára a tanórán kívüli idő jelentős részére. Az egész napos nevelésben a nevelési-képzési folyamat részévé válik az önálló tanulás és a gyermekek szabadidős tevékenységeinek irányítása is. Az egész napos nevelésben megvalósulhat a nevelési és képzési folyamat egysége, a gyermekek tanórai és tanórán kívüli tevékenységének összefüggő rendszere. Intézményes formái: bentlakásos iskola, egész napos (napközis, iskolaotthonos) osztály, egész napos (napközis) csoport, klubszerü egész napos foglalkoztatás." (Nagy, 1976, 304.)

Bognár Mária az 1980-as évek elején a következőket írja: „A nap nagyobbik részére kiterjedő iskolai foglalkoztatásra szóhasználatunkban új kifejezés is meghonosodott: egész napos foglalkoztatásnak nevezzük. Az egész napos foglalkoztatás lényege, hogy az iskolai tanórákat egész napos iskolai tevékenységgé egészíti ki. Ennek során egyenrangúnak tekintett feladat a gyerekek egyre önállóbbá nevelése az egészséges életmód gyakorlásában, a közösségi élet szervezésében, az önkormányzásban, a tanulásban, ismeretszerzésben, önművelésben, valamint a szabadidő kulturált töltésében. Legelterjedtebb szervezeti formái az iskolaotthon, a napközi otthon és a klubnapközi.” (Bognár, 1984, 3.) 
A tanulók egész napos nevelésének korszerü definícióját olvashatjuk az 1997-es kiadású „Pedagógiai lexikon”-ban: „a nap délelőtti és délutáni szakaszára kiterjesztett iskolai nevelés, amelyre általában pedagógiai és/vagy szociális megfontolásból kerül sor. Pedagógiai indíttatású egész napos nevelés valósul meg az alternatív iskolák egy részében és minden olyan intézményben, ahol a tanórán kívüli időszakban tevékenységi lehetőségek széles köre várja a diákokat. Az egész napos nevelés leggyakoribb szervezeti formái: szakkör, sportkör, önképzőkör, napközi otthon, iskolaotthon, klubnapközi, tanulószoba.” (Báthory és Falus, 1997, 313.)

Az egész napos nevelés, illetve foglalkoztatás imént bemutatott definíciói egyként hangsúlyozzák, hogy a tanulóknak a tanítási órákon túli iskolában töltött idejét az iskola ne csupán gyermekmegörzésre, illetve gondozásra fordítsa, hanem használja fel különböző nevelési feladatok megvalósítására is.

Ha a gyermekek iskolában töltött idejéről beszélünk, az általánosan használatossá vált tanítási óra kifejezés mellett kevésbé hangoztatott a tanítási órákon kívüli nevelés, vagyis az az időszak, amikor a tanulók nem a mindenki által ismeretes tanórákon ülnek. Pedig a tanórán kívüli nevelés fogalmáról már az 1978-as kiadású „Pedagógiai lexikon”-ban is olvashatunk: „Az órán kívüli nevelés a tervszerű nevelőmunkának az a formája, amelyet a különböző nevelő tényezők (tantestület, ifjúsági szervezetek, az iskolákkal kapcsolatban álló intézmények stb.) a tanórai oktató-nevelő munka kiegészítésére, elmélyítésére, a sokoldalú személyiségformálás érdekében végeznek. (...) Bár az órán kívüli nevelés folytatása a tanórán végzett nevelésnek, több vonatkozásban eltér attól. A közvetlen pedagógiai vezetés helyett inkább a közvetett vezetést valósítja meg, tartalmának, módszereinek és szervezeti formáinak kialakításában és megválasztásában jelentős szerepe van a tanulóközösség és az egyes gyermekek igényének. (...) Két fő formája az osztályon kívüli és az iskolán kívüli tevékenység. Az osztályon kívüli munkát többnyire az iskola nevelői szervezik, s színtere általában maga az iskola. Az iskolán kívüli tevékenységet nem az iskola, hanem más nevelő tényezők vezetik, s ennek megfelelően sokfélék lehetnek a színterei is. A tanórákon megalapozott, jól előkészített osztályon kívüli munka többnyire szorosan kapcsolódik a tanórákhoz, az osztály mindennapi életéhez, s túrákon, kirándulásokon, felnőttekkel szervezett találkozókon, színház-, múzeumés hangverseny-látogatásokon, különböző munkahelyekre tett tanulmányi sétákon valósul meg. Az iskolán kívüli tevékenység elsősorban a gyermekek és fiatalok életkori és egyéni sajátosságaival összefüggő sokféle igényt elégíti ki. Segíti a tanulókat az önképzésben, önnevelésben, a közösségi-közéleti tevékenységre való felkészülésben, a szabadidő egyénileg és társadalmilag értékes felhasználásában.” (Nagy, 1978, 354.)

Bár a tanítási órákon folyó nevelő-oktató munka megvalósulásában, a tanártanuló kapcsolatban, a módszerekben és a szervezés tekintetében a partnerség és az indirekt módszerek elötérbe kerülése által mára jelentős szemléletváltás történt (nyitott oktatás), a definíció mégis jól megragadja az egész napos iskolai foglalkoztatás azon lényegi jegyét, mely szerint az iskolában folyó tudatosan 
szervezett pedagógiai munkának nem a tanítási óra az egyetlen és kizárólagos színtere, de az iskolában és az iskola falain kívül is szervezhetők olyan programok, amelyek kiválóan alkalmasak nevelési céljaink megvalósítására.

Az „,egész napos” kifejezés félreérthetőségére hívja fel figyelmünket Füle Sándor. „Nem arról van szó - írja -, hogy gyermekeink a jövőben bármikor is egész napjukat az iskolában töltsék és az iskola vegye át a családi nevelés feladatait és felelősségét. Az iskolában folyó egész napos nevelésen nem egy szervezeti formát értünk, hanem - a legkülönbözőbb szervezeti keretek között annak lehetőségét, hogy az iskola a tanítási órákon kívül rendszeresen még napi 3 4 órában kiterjeszti az intézményes, szervezett pedagógiai hatását tanítványaira. Ezzel az iskola nagyobb lehetőséget kap a reá háruló feladatok megvalósítására." (Füle, 2004,)

Hazánkban a XIX. század végi gazdasági fejlődés következtében az ország nagyobb ipari központjaiban megnőtt azon gyermekek száma, akik szüleik munkába állása miatt nélkülözték a családi nevelést. A tanügyi szervek és az Európa-szerte erősödő gyermekvédelmi mozgalmak hatására emberbaráti szervezetek megőrző helyeket hoztak létre a rászoruló gyermekeknek. Így próbálták megoldani a munkásgyermekek gondozását 1890 és 1900 között.

Az első, „hivatalos” iskolában létesített napközi otthon az 1901/1902-es tanévben indult Budapest VI. kerületében. Itt képzett pedagógusok foglalkoztak a gyermekek nevelésével. A napközi müködése viszont csupán a leghidegebb, a téli hónapokra szorítkozott és csak a legszerencsétlenebb sorsú gyermekek vehették igénybe. Ám ők meleg helyiséget, étkeztetést, játék- és munkafoglalkozásokat, valamint fürösztést kaptak. A kísérlet olyannyira sikeresnek bizonyult, hogy a föváros vezetösége 1902 novemberében elrendelte: a többi kerületben is létesítsenek iskolai napközi otthonokat a rászoruló gyermekek számára. Innen számítható a napköziotthon-hálózat kiépítésének megindulása.

Az 1902/1903-as tanévben már 32 budapesti iskolában jött létre egy-egy csoporttal napközi otthon. Még csak a téli hónapokban müködtek, és elsősorban „megőrző helyek” voltak. Évről évre kiterjesztették a foglalkozásokat háromról négy, később nyolc, majd tíz hónapra. Tíz évvel később 92 napközi otthon müködött a fövárosban.

Az első világháborút követően a napközi otthonok alacsony száma miatt a szegény gyermekeknek csak kis hányada részesülhetett napközi otthoni ellátásban és nevelésben. A rászoruló gyermekek felkarolásában nagy szerepük volt az egyházaknak és a civil szervezeteknek. Az egyesületek, ha nem is feltétlenül egész napra, de legalább egy-egy délutánra összegyüjtötték öket, s számukra mese-, illetve munkadélutánokat szerveztek. Sok esetben ezeket a kezdeményezéseket próbálták napközi otthonná fejleszteni. Az 1929/1930-as tanévben az állami fenntartásúak mellett, Budapesten 23 civil szervezet müködtetett napközi otthonokat, hozzávetőlegesen 1550 gyermekkel. Mellettük több egyházközség is tartott fenn napközi otthont.

Az 1940-es évek elején már 106 fővárosi iskolában müködött egy-egy csoport. 10.000 rászoruló gyermeket tudtak befogadni. A napközik szervezése 
ebben az időszakban még nem terjedt ki hazánk minden részére. A feltételek hiánya miatt még az iparilag fejlettebb városokban is csak lassan hozták létre. Az is tény, hogy a közoktatás irányítói csak a munkásosztály gyermekeinek szánták ezeket. Az értelmiségi szülők részéről sokáig tartózkodás volt tapasztalható. A napközi otthonokat fenntartó szervezetek megfelelő anyagi forrás hiányában szerény feltételeket tudtak biztosítani. A napközi otthonok sokáig tartó lebecsülésének ez is oka lehet.

A második világháború pusztításai elérték a magyar iskolákat és azon belül a napközi otthonokat is. Épületek, berendezések, felszerelések semmisültek meg. A háború befejezése után az iskolákkal párhuzamosan megindult a napközi otthonok újjászervezése is. Ebben főként a szülők, a pedagógusok és a tanulók vettek részt. A napközi otthonok megnyitásáról az első hirdetményt 1945. január 14-én találhatjuk a Gyöngyösi Néplap hasábjain: „A Felsővárosi Napközi Otthon, Menház utca 43. szám alatt, hétfőn, folyó hó 15-én megnyílik.” Ezt követően kezdték el fokozatosan szervezni a napközi otthonokat a fövárosban és a gazdaságilag fejlettebb vidéki városokban is, s megindult egy tudatos, intenzív mennyiségi fejlesztés. Az 1948/49-es tanévben az összes általános iskolai tanuló 1,6\%-a volt napközis. Tíz évvel később arányuk 5,7\%-ra emelkedett. Az 1964/1965-ös tanévben a tanulók 11,2\%-a részesült napközi otthonos ellátásban, négy évvel később arányuk további 4,5\%-kal növekedett, 1979-re pedig elérte a 18,8\%-ot. A napközi otthonba felvett szegény sorsú gyermekek számára biztosítani tudták az alapvető feltételeket: tantermeket, fütést, berendezéseket, felszereléseket és az étkeztetést. Erőteljes törekvés mutatkozott arra nézve is, hogy e speciális munkában képesített, jól felkészített pedagógusok vegyenek részt.

A rendszerváltás első éveiben csökkent a napközis tanulók aránya. Nézetem szerint ennek legföbb okát abban kereshetjük, hogy a családok reménykedtek: a demokratikus Magyarországon a nöknek nem kell dolgozniuk ahhoz, hogy eltartsák magukat. Az 1992/1993-as tanévre a kezdeti csökkenésben megállás mutatkozott, s innentől kezdve egyre növekvő igény tapasztalható a napközi otthonok iránt (Füle, 2002).

A napközi otthonok kialakulását és erőteljes fejlödését kezdetben legföképpen szociális igények indukálták. Erre az igényre válaszoltak az iskolák és az előbbiekben bemutatott szervezetek, s a pedagógia eszközeit használták fel, igen helyesen, a megoldáshoz. Mára a napközi otthonok iránti igény árnyaltabb képet mutat. Hazánk több területén ma is erőteljesen kidomborodik a napközik szociális feladata. Ma is vannak olyan családok, ahol a gyermekek számára csak így biztosított a meleg ételhez jutás. Sok esetben gyermekvédelmi feladatokat lát el a napközi azáltal, hogy felügyeli, oktatja, neveli a veszélyeztetett gyermekeket, s szabadidejüket megszervezve megelözi az antiszociális viselkedés kialakulását. A napközi otthonok eme „hagyományos” funkciója mellett jelenlévőként kell kezelnünk, hogy egyre nagyobb számban vannak olyan szülök, akik szeretnék, ha az iskola a kötelező órákon kívüli időben több olyan foglalkozást biztosítana, amelyeken gyermekeik még több tudásra tehetnek szert, érdeklödési körükben 
még alaposabban elmélyülhetnek. Ezeket a „különórákat” a napközi otthonok kénytelenek müködési rendjükbe beilleszteni, s az iskola tanulói és a tanári kar összetétele, valamint a helyi feltételek függvényében új feladatok vállalásával rugalmasan alkalmazkodniuk kell az elvárásokhoz.

A gyermekek egész napon át történő foglalkoztatásának, egy teljes napjuk egységbe szervezésének másik útja az iskolaotthon, mely szintén a testi-lelkiszellemi nevelés összehangolt megvalósítására törekszik. Az egész napos iskolai foglalkoztatás e formájában a pedagógiai feladatok megosztása a tanítók között nem különül el a délelőtti tanításra és a délutáni foglalkozások irányítására. „A tanító is, a napközis nevelő is nyer vele, ha a leckekészítés alatt a tanító van jelen, s cserében a napközis nevelö néhány - a szabad időbe szervesen beilleszthető tantárgy (testnevelés, ének, gyakorlati foglalkozás, rajz) tanítását vállalja. A tanító a felkészülés alatt pontosan le tudja mérni tanórai eredményességét, másrészt differenciált feladatokat adhat. A napközis nevelö, mivel nem tudhatja, milyen volt a gyermekek aktivitása a tanórák alatt, olykor kénytelen a tanulás megkezdése előtt az után nyomozni, mennyire értik a feladatokat, kinek van szüksége segítségre. Az új munkarend mindezt kiküszöböli” - írja Eperjessy Gézáné az iskolaotthonos szervezés indoklásaként (Eperjessyné, 1981).

1964-ben indult meg az Országos Pedagógiai Intézet szervezésében az ún. „egész napos iskola”-kísérlet. A tapasztalati eredményekről így számol be Szabadkai Simonné, a kísérlet vezetője: „Az osztályok vezetését az alsó tagozatban két nevelöre bíztuk, akik között a tantervi órákat úgy osztottuk el, hogy egyikük az anyanyelvi tárgyak, másikuk a számtan-mértan, környezetismeret és egyéb tárgyak tanításával foglalkozott. A nevelök napi váltásban tanítanak. Ennek következtében az egyik napon délelöttre, másik napon délutánra kerülnek az anyanyelvi tárgyak, s a többi tárgy ennek megfelelően fordítva. Aki délután tanít, az másnap délelöttös. Igen fontos követelmény, hogy a tanítási órát vezető pedagógus felügyelete mellett készüljön el a tanulók házi, illetve iskolai feladata. Az új munkaritmus megteremtésével a gyermekek teljesítöképessége magasabb színvonalat ér el, ennek következménye jobb tanulmányi eredményekben tükröződik." (Szabadkainé, 1968, 9.)

1964 és 1968 között az Országos Pedagógiai Intézet három, két vidéki és egy budapesti, kísérleti iskolájában indított iskolaotthonos szervezéssel osztályokat. A kísérlet ideje alatt megvizsgálták a tanulók kifáradását. A vizsgálat eredményének hatására meghosszabbították a szabadban töltött időt. Az óraközi szüneteket az udvaron töltötték a gyermekek, a tornaórákat lehetőleg a szabad levegőn tartották számukra, s mindezeken túl még minden nap 1 óra 20 percen át folytattak mozgásos tevékenységeket a szabadban.

Az 1968/69-es tanévben 3 iskolaotthonos osztályt szerveztek elsős osztályok számára. A gyermekek életkori sajátosságaihoz igazodva, s a korai kelés ellensúlyozása végett, megszervezték a tanulók ebéd utáni altatását is. Második osztálytól már nem volt kötelezö az alvás, de a feltételek adva voltak azok számára, akik élni kívántak vele. Az osztályok átlagos felszereltséggel müködtek. A folyamatosan bővülö tapasztalatok alapján azonban úgy igazították 
az osztályok berendezéseit, hogy azokban a tanulás mellett játékra és a szabadidős foglalkozások végrehajtására egyaránt lehetőség nyíljon. Egyre elterjedtebbé váltak a mozgatható padok, melyekkel nemcsak az aktuális tevékenység végrehajtására tehették alkalmassá a teret, hanem, szemben a rögzített padsorokkal, még otthonosabb érzést is kölcsönzött. A termekben játszósarkok alakultak, megfelelö térrel és eszközökkel.

Az iskolaotthonos osztályok népszerüségre tettek szert a szülök körében is. Ennek is köszönhető, hogy napjainkban, az intézmény méretének függvényében, szinte minden iskolában találkozhatunk az egész napos nevelés e formájával.

2011. december 29-én az egész napos iskola fogalma törvényi keretek közé került. A 2011. évi CXC. törvény a nemzeti köznevelésröl 4. §-ában - az értelmező rendelkezésekben - a következőképpen definiálja: „Egész napos iskola: iskolaszervezési forma, ahol a tanórai és más foglalkozásokat a délelőtti és délutáni időszakra egyenletesen szétosztva szervezik meg." A törvény szellemiségében azt a több évtizedes tapasztalatot erősíti, mely szerint a tanulók egész napos iskolai foglalkoztatása széles körü lehetőséget nyújt a gyermekek tudásának bővítésére, a tapasztalatszerzésre, a közösségi élet fejlesztésére és az önálló személyiség kibontakozására. Változatos tevékenységek és jó hangulatú légkör biztosításával fenntartható a tanulók magas motivációs szintje, ami az ismeretszerző és a szociális tanulásnak egyaránt alapja.

\section{A kutatás és az eredmények bemutatása}

A köznevelés jelen helyzetében kutatásunk a pedagógiai gyakorlat vizsgálata által kívánta feltárni az egész napos nevelömunka (az iskolaotthon, a napközi otthon és a tanulószoba) aktuális helyzetét öt megye (Komárom-Esztergom, Fejér, Veszprém, Zala és Tolna) általános iskoláiban. A mintavétel ideje a 2011/2012-es tanév eleje volt, tehát a pedagógusok véleményét azt megelőzően kértük, hogy a nemzeti köznevelésről szóló törvény jogszabályhelyei ismertekké váltak volna. Vizsgálatunk során a nevelők szemszögéből fókuszáltunk az egész napos iskolai foglalkoztatásra, hogy véleményük ismeretében következtetéseket tudjunk levonni az egész napos iskola bevezetésére vonatkozóan.

A kutatásban ezért a következő kérdésekre kerestük a választ: Mely szervezeti formákat használják leggyakrabban? Melyek a pedagógusok által legfontosabbnak gondolt - az egész napos nevelömunkával kapcsolatos nevelési-oktatási célkitüzések? Hogyan használják ki a pedagógusok az egész napos nevelésben rejlö lehetöségeket? Mi a véleményük az egész napos iskola általános bevezetésével kapcsolatban?

A kérdések megválaszolásához szükséges adatokat a kérdőíves kikérdezés módszerével gyüjtöttük össze. A kérdőíveket 236 pedagógus töltötte ki. Közülük az alsó tagozaton tanítók száma 176 fó, a felső évfolyamon tanítók száma pedig 60 fö volt.

A megkérdezett tanítók és tanárok az egész napos nevelés különböző típusaiban az alábbi arányban dolgoztak: 


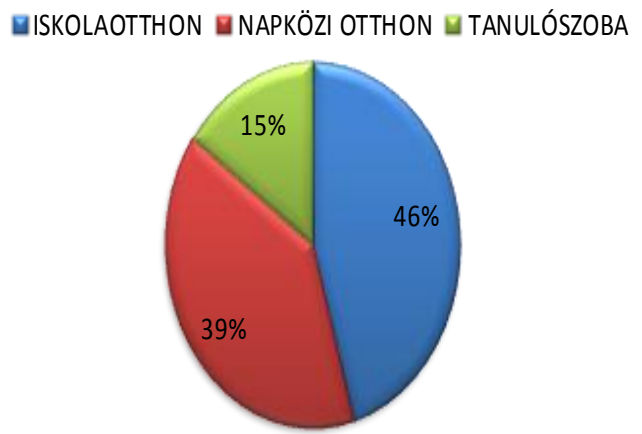

A diagramon jól látható, hogy az iskolaotthon és napközi otthon szervezeti formákban összesen a megkérdezettek 85\%-a tanít, ugyanakkor a vizsgált pedagógusok körének csupán 75\%-a tanító. A kérdöívek elemzésekor kiderült, hogy a felsős szaktanárok 10\%-a tanít az alsóbb évfolyamokon is, fóként iskolaotthonos formában.

$\mathrm{Az}$ iskola mint szervezet szerteágazó tevékenységek rendszerének müködtetését kívánja meg. A közös célok elérése érdekében belső munkamegosztás van a nevelötestület tagjai között. Ezért a vizsgálatban feltett kérdéseink kitértek a pedagógusok különböző feladatköreinek feltárására is. A megkérdezett általános iskolai tanítók és tanárok mindegyike tanít az egész napos nevelés valamely szervezeti formájában. Arra voltunk kíváncsiak, hogy ezen a munkán felül, még milyen más jellegü tevékenységeket végeznek. Az eredményeket elemezve látható, hogy a pedagógusok több mint egyharmada az adott szervezeti formában történő tanításon kívül nem tölt be más funkciót. A megkérdezettek közel felének van más jellegü feladata is, 14\%-uk pedig kettő vagy annál több állandó vagy rendszeres feladatot is végrehajt.

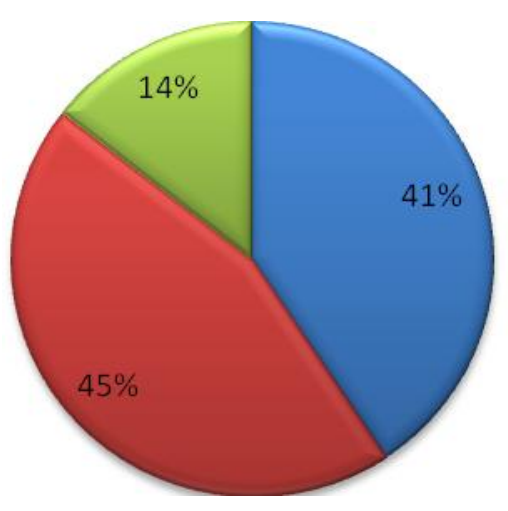

$\square$ NINCSFUNKCIÓJA

EGY FUNKCIÓJA VAN

$\triangle$ KETTÖ VAGY ANNÁL TÖBB FUNKCIÓT LÁT EL 
Az iskola szervezetén belül végzett feladataikat az alábbiakban nevesítették:

Szerepkörök:

Szaktanár

Szakmai munkaközösséget vezet

Iskolai szervezetek tagja vagy vezetője (Közalkalmazotti Tanács, Minőségbiztositási csoport), illetve speciális feladatkör ellátását végzi (gyermekvédelmi felelös, szabadidö szervezö, diákönkormányzat munkáját segítő tanár)

Osztályfönök

Igazgató, igazgató-helyettes vagy tagozatvezetö

Tanári, illetve tanitói végzettségük mellett gyógypedagógus, fejlesztö pedagógus, illetve gyógytestnevelö végzettséggel is rendelkeznek, s ezeken a területeken is látnak el feladatokat
Létszám:

$81 f^{\prime \prime}$

$34 f^{\prime \prime}$

$19 f^{\prime \prime}$

$8 f^{\prime \prime}$

$8 f o$

Az egész napos nevelés különböző formáiban szerzett munkatapasztalatuk időtartamára vonatkozó kérdésünkre a megkérdezettek 5,93\%-a nem adott értékelhető választ. A pontosan válaszoló 222 fó általunk vizsgált tanítási, nevelési formákban eltöltött idejét 5 éves intervallumokba csoportosítottuk, s a gyakoriságot az alábbi diagramon jelenítettük meg:

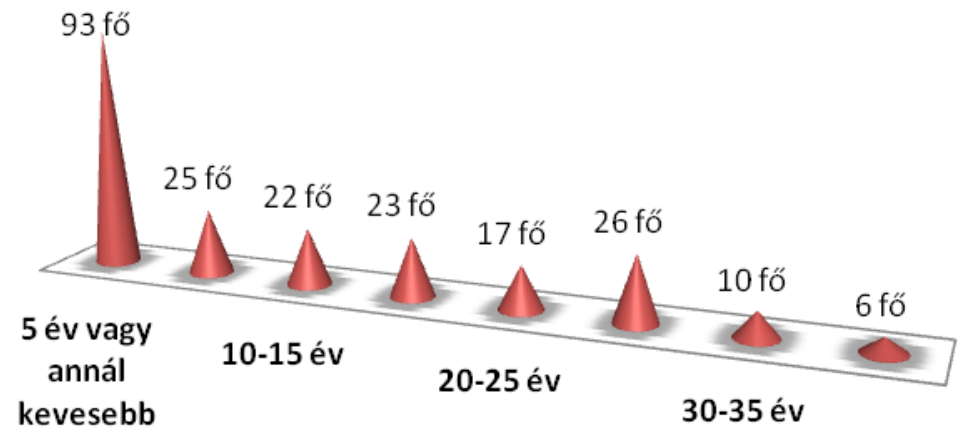

A megkérdezettek 26,57\%-a több mint húsz éve dolgozik az egész napos nevelés valamely formájában. Közülük sokan jelezték, hogy napközis nevelöként dolgoznak a pályára kerülésük óta. 41,89\% azok aránya, akik öt évnél kevesebb ideje végzik ezt a munkát. Felhívnánk azonban a figyelmet arra, hogy az oszlopdiagramok nem a tanításban, hanem az egész napos nevelésben eltöltött időt mutatják, tehát itt nem a pályakezdők magasnak mondható arányáról van szó!

A pedagógusok egész napos nevelőmunkával kapcsolatos érzelmi irányultságának feltárása érdekében feltettük számukra a kérdést: mi motiválta, hogy egész napos nevelőmunkában vegyen részt? $\mathrm{Az}$ alaposabb kiértékelhetőség érdekében a kérdésre adott válaszaikat két csoportra bontva kértük megadni. Kíváncsiak voltunk a belső indítékokra, de a külső 
körülményekre, okokra is. A megkérdezettek 10\%-a nem jelölt meg külső körülményt, ebből $4,66 \%$ belső indítékot sem!

A válaszokat Cluster-analízissel csoportokba rendeztük, melyek százalékos gyakoriságát diagramok segítségével kívánjuk bemutatni. Elsőként a külső körülményeket ábrázoljuk:

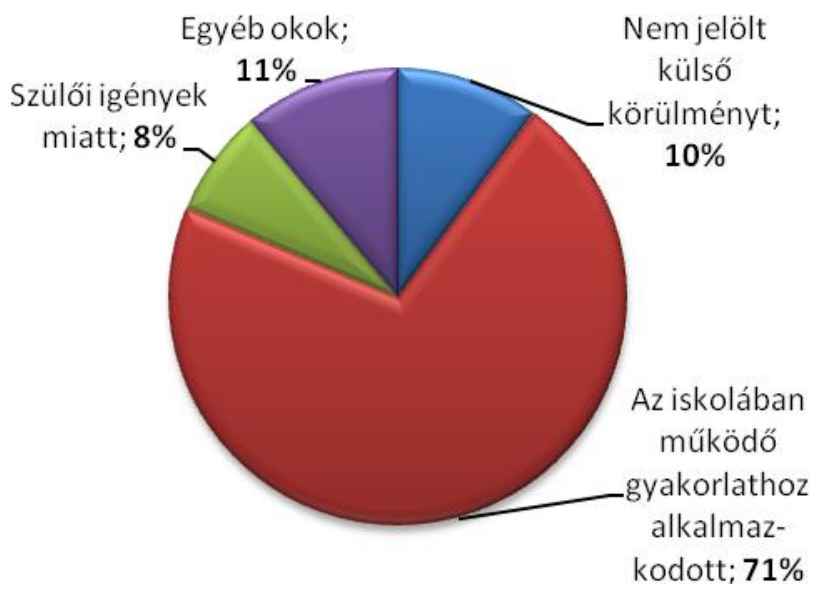

A megkérdezettek majdnem háromnegyede az iskolában müködö gyakorlathoz alkalmazkodott. Sokan már pályakezdőként ebbe a formába kerültek, jelentős részük, azóta is napközi otthonban dolgozik. Többen azt jelölték indokként, hogy a kisebb gyermeklétszám miatt csak egy első osztály indult, így „lekerültek” napközibe. A felsőbb évfolyamokon tanítók között többeknek csökkent szakján az óraszáma, ezért vesznek részt a tanulószobai foglalkoztatásban. A csoporton belül a megkérdezettek 11\%-a vezetői döntés miatt vesz részt az egész napos nevelés valamely formájában: „Ezt a feladatot osztották rám”, ,,Tantestületi döntés eredményeként vagyok itt”, „Fenntartói elvárások miatt kellett bevezetnünk, azóta itt vagyok".

Szülöi igényekre hivatkozott a pedagógusok 8\%-a. Az egész napos iskolai ellátás igénye abból fakad, hogy sok szülő elfoglalt délután, s az iskolában tudja legjobb helyen gyermekét. Más részük nem tud segíteni gyermekének a tanulásban, ezért igényli a délutáni foglalkozásokat. A csoporton belül jelentős arányban szerepel indoklásként a családok szociális helyzete, illetve a tanulók rászorultsága a nagyobb arányú fejlesztésre.

A válaszok 11\%-a az egyéb csoportba volt sorolható. A pedagógusok közül többen azért döntöttek az egész napos nevelömunkában való részvétel mellett, mert jobbnak érzik az időbeosztásukat. Délutáni foglalkozások vezetése esetén délelőtt jut idejük a saját családjuk körüli teendőik intézésére (pl. főzés, vásárlás, háztartási munkák, saját gyermek eljuttatása óvodába stb.) Sokan, s főként az iskolaotthonban dolgozók közül, azért választották ezt, mert itt két pedagógus dolgozik együtt. A feladatok és a felelösség egyaránt megosztható és több idő jut az alapos felkészülésre. Néhányan azért motiváltak e munkára, mert 
lakóhelyükhöz közel dolgozhatnak. Másoknál a családi körülményeikben beállt változások játszottak szerepet.

Nagyon figyelemre méltó, hogy a megkérdezett pedagógusok 39,40\%-a nem írt belső indítékot, ugyanakkor közülük 34,74\% írt külső okokat. Eszerint $a$ válaszolók közel negyven százaléka mindenféle belső indíttatás nélkül dolgozik az egész napos nevelés valamely szervezeti formájában!
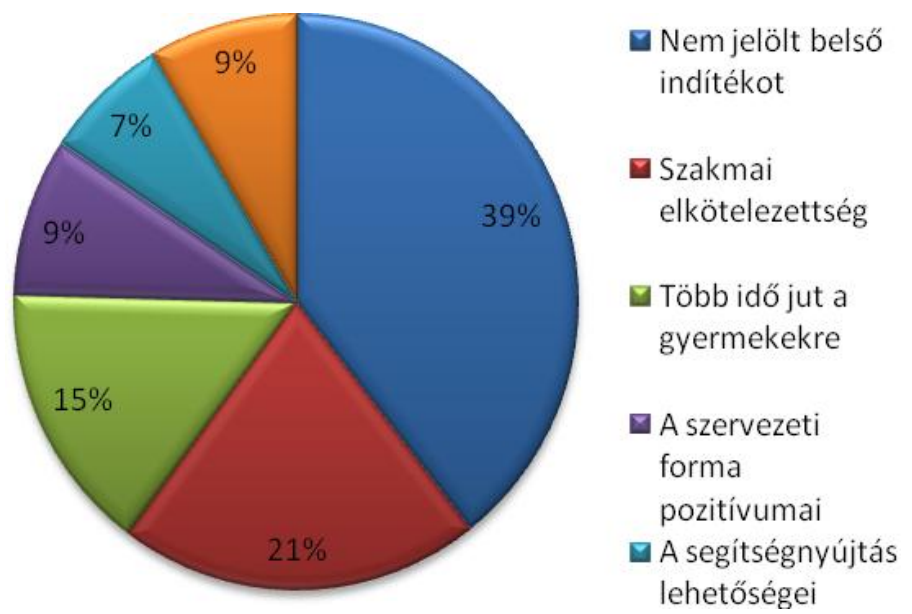

Az összes megkérdezett ötöde hivatkozott csupán a tanítás szeretetére, szakmai elkötelezödésre, amit a következökkel fejeztek ki: „Szeretem, amit csinálok”; „Szívesen vállaltam”; „Megismertem, megszerettem”; „Szakmai kihívást okoz”; „Tudatosan készültem rá”; „Korábbi jó szakmai tapasztalatok motiváltak”; „Érdekelt”; „A szakmai fejlődés lehetőségét láttam meg benne”. A pedagógusszakma szeretete mellett erős motivációs tényező e csoporton belül a gyermekek iránti szeretet, a velük való foglalkozásban található öröm.

A megkérdezettek 15\%-a azért tartja vonzónak az egész napos nevelömunkát, mert itt több idö jut egy-egy tanulóra. Ez pedig a gyermekek alaposabb megismerésének lehetőségét rejti magában. A személyiségüket sokkal több oldalról meg lehet ismerni, s ezáltal az osztályközösség is jobban formálható. Szeretik az egész napos nevelésben, hogy a tanulók egész nap megfigyelhetők, több alkalom van segíteni a tanulást, jobban lehet differenciálni.

A belső indíttatás okaként $9 \%$-ban a szervezeti formában rejlö pozitívumokat sorolták fel. Az egész napos nevelésben való részvételüket a tantárgyfelosztással indokolók az iskolaotthonos szervezeti formában tanítanak. Véleményük szerint a tantárgycsoportos tanítás kedvezőbb, mert kevesebb tantárgy jut egy pedagógusra, a feladatok egyenletesebben oszlanak el, arányosabb a munkamegosztás és több idő jut a felkészülésre. Többen hangsúlyozták a szervezeti keretek rugalmasabb, kötetlenebb voltát. Néhányan azért kedvelik, mert a tanítás mellett lehetőségük nyílik a szabadidő szervezésére 
is. Mások a kollégákkal való jobb együttmüködés miatt szeretnek az egész napos nevelőmunka szervezeti formáiban dolgozni.

A válaszolók 7\%-a belső indítékként a segítségnyújtás különbözö lehetőségeit nevezte meg. A rászorulóknak nagyobb segítséget lehet adni, a bukásokat jobban el lehet kerülni, több foglalkozásra van lehetőség a gyengébb tanulókkal. Több segítséget lehet nyújtani a leckeírásban, a másnapra való felkészülésben. Nyugodtabb körülmények között, nagyobb figyelemmel lehet végigkísérni a tanulást.

Az egyéb okok között szerepeltek olyan válaszok, melyekben az állásuk féltését nevezték meg legerősebb belső indíttatásnak a pedagógusok: „Örülök, hogy dolgozhatok!”; „Ragaszkodtam az állásomhoz, hát elfogadtam a körülményeket!’. Sokan érzik úgy, hogy e szervezeti formában többet tehetnek az óvoda-iskola közötti átmenet enyhítése érdekében. Mások azért kedvelik, mert a gyermekek számára fontos állandóság itt jobban megvalósítható. A válaszok között többször is szerepelt belső indítékként az a tény, hogy ilyen keretek között tanult maga a pedagógus is.

A kérdöíveken arra is kértük a tanítókat, tanárokat, soroljanak fel 3 okot, ami miatt örömmel végzik munkájukat, s 3 okot, amely elkedvetleníti őket feladatvégzés közben! A felsorolt okokat tartalomelemzésnek vetettük alá, majd Cluster-analízis segítségével csoportokba soroltuk. Az egyes csoportok gyakoriságának százalékos arányát diagramokon rögzítettük. A munkában lelt örömök gyakoriságát nem az összes válasz, hanem az összes megkérdezett arányában adtuk meg:

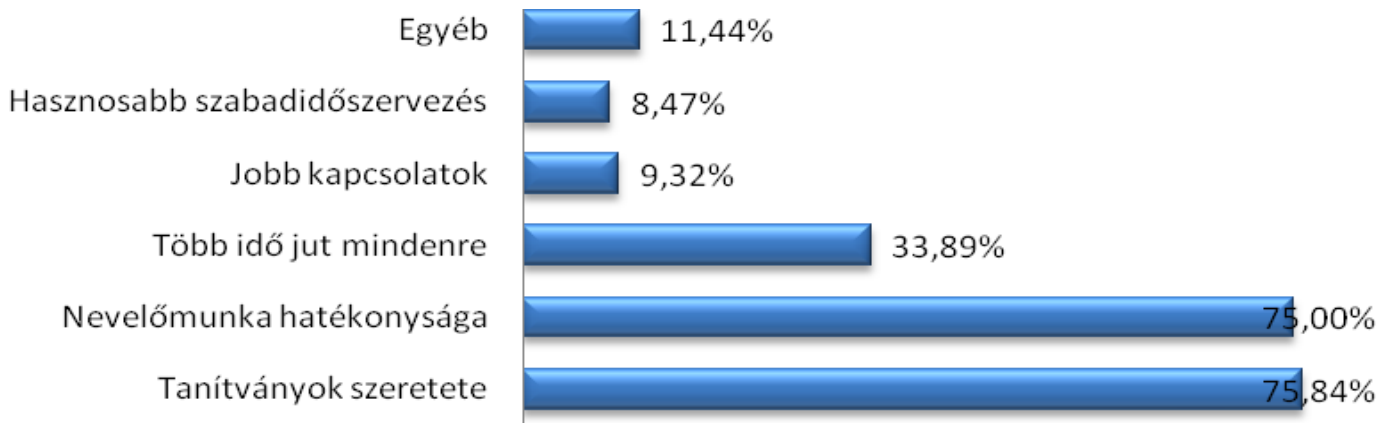

A diagramon jól látható, hogy a legnagyobb gyakoriságot képviselö cluster a tanítás és a tanítványok szeretetével kapcsolatos, azaz a pedagógusok leginkább ezen okok miatt találnak örömöt az egész napos nevelömunkában. Kifejezték, hogy a gyermekekkel öröm foglalkozni, hálásak, sok szeretetet kapnak tölük, ragaszkodnak egymáshoz és tanítójukhoz. A tanulókat jól motiválhatóknak, lelkeseknek tartják. Sok pozitív visszajelzést kapnak a gyermekektől, akik fogékonyak a tanulás iránt, így együtt örülnek az eredményeknek. A gyermekek egyéni fejlődése, tudásuk bővülése sikerélményhez juttatja tanáraikat. A válaszok tartalomelemzése alapján elmondható, hogy a megkérdezettek az egész napos 
nevelés különböző formáiban jobban megismerhetőnek vélik a tanítványok teljesítőképességét, személyiségét, problémáit, magatartását. Nagy arányban jelent meg a csoporton belül a hivatástudat, a szakmaszeretet, az elhivatottság mint örömforrás: „Ez a munka jó lehetöség a továbbfejlödésre”; „A tanitás gyermekkori álmom valóra válása”; ,Minden nap új kihívás számomra”.

Hasonló arányú gyakoriságot képvisel a nevelömunka hatékonysága miatt érzett öröm kifejezéseit tartalmazó cluster. Jó érzéssel tölti el a pedagógusokat, ahogy formálódik a közösség, ahogy gyermekek között barátságok szövődnek. Igyekeznek bensőségesebb kapcsolatot kialakítani tanár és diák között, ,, közelebb kerülni a gyermekek lelkéhez”. Örülnek, hogy a tanulók szívesen járnak iskolába. Kifejezésre juttatták, hogy délután a nevelés hangsúlyosabb, s itt „erkölcsi értékekre lehet tanitani”. Hatékonynak érzik a tanulásban való segítségnyújtást is. Úgy gondolják, az egész napos nevelőmunkában jól nyomon követhető a gyermekek tanulása, segíteni tudnak a házi feladat elkészítésében, az ismeretszerzésben, nagyobb lehetőség van a tanulási módszerek megtanítására, a tananyag rögzítésére, gyakorlására. Jobban nyomon követhetőek a fejlődés, illetve a megértés problémái, hamarabb kiderülnek a tanulási nehézségek. Ebben az esetben az elmaradásokat pótolni lehet, a lemaradók felzárkóztatása eredményesebb, a gyengébb tanulókkal külön lehet gyakorolni, hatékonyan lehet segíteni a bukásra állóknak. A tehetségek gondozása is megjelent a válaszok között. Szeretik a pedagógusok, hogy versenyekre készíthetik fel a tanulókat, tovább tudják fejleszteni a tehetségeseket.

A megkérdezett pedagógusok harmada kedveli, hogy az egész napos nevelömunka sok szabadságot ad és több idö jut mindenre. Nagyobb az esély a munka és a pihenés, a tanulás és a sport arányainak megteremtésére. Több közös programra, gyakorlásra nyílik lehetőség. Nyugodtabb a munkatempó, több idő jut kötetlen beszélgetésre, az örömteli együttlétre. Rugalmas az időrend, ami alkalmazkodik a gyermekek teherbíró képességéhez. Sokrétü és változatos munkának érzik.

A szülőkkel, a kollégákkal kialakult jobb kapcsolatot a válaszolók majdnem tíz százaléka nevezte meg a munkájában érzett öröm forrásaként. A megkérdezettek úgy érzik, hogy párban jobban lehet dolgozni, s a tapasztalt kollégáktól tanulni lehet. Napi kontaktusra van lehetőség a szülőkkel, s ez pozitívan befolyásolja a tanár-szülö kapcsolatot is.

A szabadidő jobb megszervezésének lehetőségeit 8,47\%-ban írták okként. A gyermekek hasznosan töltik szabadidejüket, változatos tevékenységeket tudnak kínálni számukra, s a szabadidőt felügyelet alatt tölthetik.

Az egyéb kategóriába sorolt válaszok között a pedagógusok örömforrásként jelölik meg, hogy pl. „fejlettek az oktatási eszközök”, „hosszú a nyári szünet”, „e munka fizikailag nem megterhelő” és ,betekintést lehet nyerni a többi tantárgyat tanítók munkájába".

Arra a kérésünkre, hogy soroljanak fel három okot, ami elkedvetleníti őket feladatvégzés közben, a megkérdezettek $9 \%$-a azt felelte, nincs ilyen, nem tud megnevezni semmit. A többiek válaszainak elemzésekor arra a 
következtetésre jutottunk, hogy csupán négy csoport felállítása szükséges. A megnevezett okok mindegyike alapvetően valakire (tanulókra, szülőkre, iskolavezetésre), illetve valamire (társadalom, pedagógusszakma) vonatkoztatható. Az egyes csoportok gyakoriságának százalékos arányát mutatja az alábbi kördiagram:

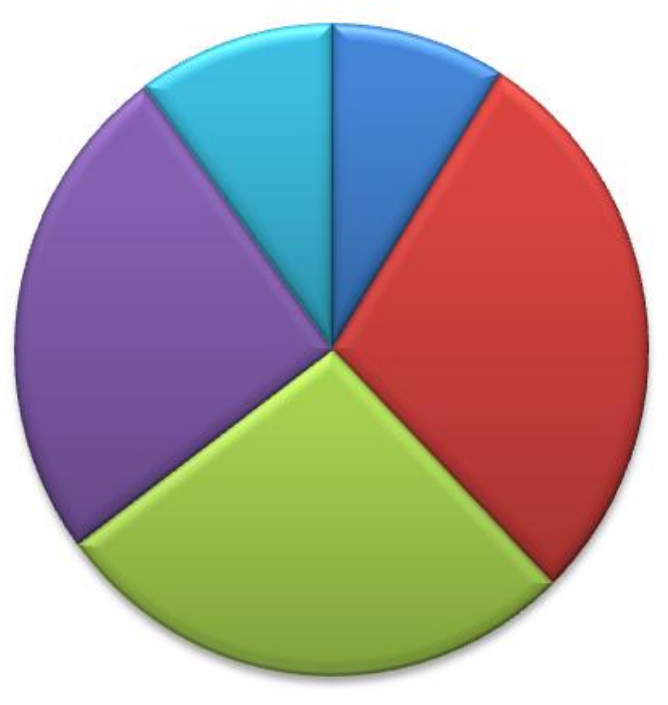

\author{
$\square$ Semminem kedvetleníti el \\ - Tanulótól származó okok \\ 凹Szülőktől származó okok \\ Iskolavezetéstől, \\ társadalomból származó \\ okok \\ 凹 Szakmai problémák
}

A tanulóktól származtatott okok a pedagógusok közel egyharmadát kedvetlenítik el. Véleményük szerint a tanulók délutánra rendszerint fáradtak, nem képesek ugyanúgy figyelni, mint délelőtt, sok fegyelmezésre van szükség. „Több időt kell szánnom a fegyelmezésre, mint ami szerintem a megengedett lenne.” „Délután már életkori sajátosságuk miatt fáradtak.” „Sokszor fáradt, zaklatott gyerekekkel dolgozunk."

A tanulók körében sok a magatartási nehézséggel küzdő, akikkel délután nehezebben boldogulnak. „Egyre több problémával érkeznek a gyerekek az iskolába.” „Egyre több a magatartási probléma a gyerekek körében.” „A nehezen kezelhetö gyerekek ebben a szervezési formában még nehezebben kezelhetök, korrepetálni csak szabadidöben lehet, így egyre fáradtabb gyereket próbálok felzárkóztatni."

Hivatkoznak a gyermekek érdektelenségére, rendetlenségére, hiányos felszereltségére. Az okok között szerepel a tanulókon felfedezhető családi nevelés hiánya, az érzelmi elhanyagoltság, illetve a túlterheltség is. „Elszomorit, hogy a tanulók egy része igen nehezen motiválható." „Elszomorit az igénytelen munka, a rendetlen felszerelés, a felszerelés hiánya." „A gyerekek túlterheltek, a teljesitménykényszer a szabadidöt rövidíti meg." „Nö az emocionálisan sérült gyermekek száma."

A tanítók, tanárok elkedvetlenedésük okait a tanulók rossz szokásaiban is látják. „A gyerekek többsége szabadidejében a számítógép elött ülne, a számitógép fontosabb, mint egy jó mozgásos tevékenység, a sport.” „Nagyobb társaiktól hamar eltanulják a trágár beszédet, a nyegle viselkedést, a rossz magatartást." 
A szülöktöl származtatott a felsorolt okok közel harminc százaléka. A pedagógusok alacsonynak vélik a szülők motivációját gyermekük tanulmányait illetően. „A szülök nehezen vonhatók be a következetes munkába.” „A szülök passzivak, többségük érdektelen gyermekük iskolai munkája iránt.” „Néhány szülö úgy érzi, az egész napos neveléssel teljesen levettük válláról teendöit."

Úgy érzik, a szülök nem becsülik eléggé munkájukat. „Elszomorit, hogy nem kellöen becsülik meg az eröfeszitéseinket.” „Ennek a munkának nincs akkora becsülete a szülők körében."

Úgy vélik, a családokban a gyermekek túl sokat ülnek a televízió és a számítógép előtt és ennek negatív hatásait érzik a délutáni iskolai foglalkozásokon. Hiányzik a gyermekneveléshez nélkülözhetetlen nyugodt, szeretetteljes családi háttér. „A média, elsösorban a kereskedelmi csatornák, illetve az internet népszerü közösségi oldalai nagymértékü rombolást tudnak végrehajtani, elferdült értékrendet közvetitenek, a gyerekeket a fogyasztó társadalom rabjává teszik.” „Nincsenek közös családi programok.” „Egyre rosszabb a gyerekek neveltségei szintje, amit a szülöi házból hoznak magukkal." „A szülöknek egyre kevesebb idejük van a gyermekükkel foglalkozni, mesélni, beszélgetni velük. A problémák megoldását az iskolától várják."

A kapcsolattartás nem kielégítő voltára is hivatkoznak, amit a szülők érdektelenségének tulajdonítanak. „Egyre nehezebb a szülőkkel a kapcsolatot tartani, nincsenek tisztában a gyerekek képességeivel, fejlödésével."

A megkérdezettek negyede sorolt fel olyan okokat, amelyek az iskola vezetésének kompetenciáit, illetve társadalmi megítélést érintik. Elkedvetleníti a pedagógusokat, hogy úgy érzik, az iskola szervezetében a délutáni foglalkozások mellőzöttek, figyelmen kívül hagyottak a szervezés, a tárgyi felszereltség, a források tekintetében. „Kevés olyan tárgyi eszközzel rendelkezünk, amely igazán otthonossá tenné a tanulók ittlétét. Ugyancsak hiányolható a sportolási lehetöségek eszköztára. Ha ilyen megnövekedett feladatoknak kell eleget tennünk, még több pályára, sportolási lehetöségre lenne szükség. Szintén fontos lenne még több internet hozzáférés, hogy valóban meg tudjunk felelni programunknak.” „A termemet 10 éve nem meszelték ki, mert nem jutott rá pénz.” „Kevés eszköz adott a minöségi munkavégzéshez."

Negatív érzéseik a pedagógusszakma anyagi és erkölcsi megbecsültségének, helyzetük stabilizálásának nem megfelelő voltából is fakadnak. „Nem kapunk elegendö megbecsülést. Nem beszélve a nevetséges fizetésünkröl, aminek egy részét visszahordjuk az iskolába különbözö anyagokra, papírokra és egyéb nélkülözhetetlen írószerekre költve.” „Rossz a pedagógusok társadalmi megitélése, megbecsülése, anyagi és erkölcsi vonatkozásban is." „Sok az egyéb, tanitáson kivüli feladat, és a meggondolatlanul hozott rendelkezések. ",Állandó a bizonytalanság."

A napközis nevelőket elszomorítja a nevelőtestületben elfoglalt helyük és szerepük megítélésének negatív volta. „Kollégák gyakran lenézően viszonyulnak a napközis munkához.” „Lenézik a munkánkat - »csak napközis«!” 
A válaszok 10\%-a a megkérdezettek szakmai problémáira vezethető vissza. Úgy érzik, hogy az egész napos nevelőmunka nehezebbé teszi eljutásukat szakmai továbbképzésekre. Kevesebb idejük marad a felkészülésre, így nem tudják céljaikat elérni: „A továbbképzésekre nehezebben jutok el.” „Kevesebb időm marad a másnapi felkészülésre."

Sokan úgy érzik, az egész napos nevelömunka nagyon leterhelö, fárasztó számukra. „,Több energiát vesz ki belölem, mint a hagyományos munkaformák.” „Bármennyi idöt töltök az iskolában, mégis úgy érzem, soha nem jutok a feladataim végére." „Már nehezebben bírom energiával a hosszú napokat."

A vizsgálatban megkértük a résztvevőket arra is, soroljanak fel 5 célt, melyek elérését a legfontosabbaknak érzik az egész napos nevelés területén végzett munkájukban. Figyelemre méltó tényként kell közölnünk, hogy a megkérdezettek 17,79\%-a nem tudott vagy nem akart 5 célt felsorolni. Az adatok vizsgálatánál ismételten a tartalomelemzés módszerét választottuk, $\mathrm{s}$ a válaszokat három nagy kategóriába soroltuk. Az egyes kategóriák gyakoriságának százalékos arányát az összes válasz számához mértük.

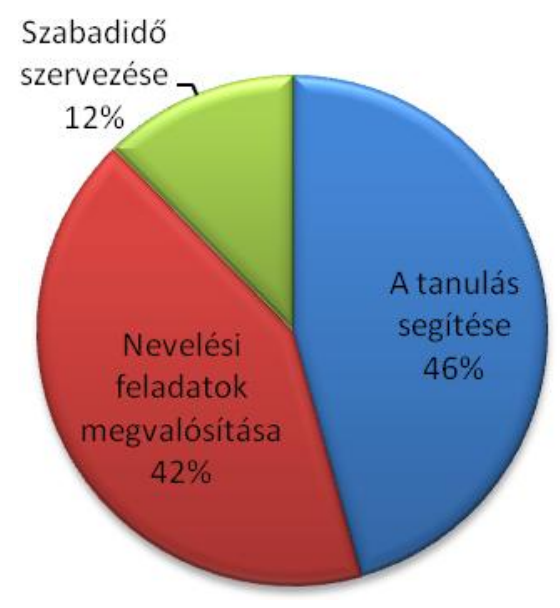

Az eredmények tükrében kijelenthetjük, hogy a pedagógusok számára az egész napos nevelőmunkában a legfontosabb a tanulás segítése. Ez egyrészt jelenti a tanulók felkészítését a másnapi órákra, a tanulás tanítását, a helyes tanulási szokások, a változatos tanulási formák kialakítását, a korszerü tanulási módszerek tanítását, alkalmazását, $\mathrm{s}$ mindezek mellett természetesen a házi feladat elkészítését, hogy otthon már ne kelljen a tanulóknak a leckével foglalkozniuk. Másrészt szeretnék a gyengébb képességü tanulókat, a lemaradókat, a lassabban haladókat felzárkóztatni, a hátrányos helyzetü tanulókat segíteni, lehetőséget adni a pótlásra, hogy ezáltal mérséklődjenek az esélykülönbségek, enyhüljenek a szociokulturális hátrányok s megvalósuljon a bukásmentes iskola. Harmadrészt a képességek fejlesztése és a tehetséggondozás is szerepel a célok között. A képességek több oldalról történő fejlesztése célzott feladatokkal, illetve a tehetséges tanulókkal való egyéni foglalkozás és 
versenyekre való felkészítésük is nagyon fontos megvalósítandó feladat a nevelők számára.

A tanulást segíteni kívánják annak megszerettetésével, hogy ezáltal a tanulók motiváltabbak legyenek az önálló ismeretszerzésben, s önállóan végezzék feladataikat, különösen a házi feladatot. Az önálló tanulást fokozatosan, megfelelö tanulási módszerek alkalmazásával alakítanák ki. Mindemellett az alaposabb tudás megszereztetése is fontos célkitüzésként szerepel. A tudás legyen érték, a tanulók tegyenek szert alaposabb ismeretekre, s legyen igényük annak megszerzésére.

A legfontosabb célok másik nagy csoportja a nevelési feladatok megvalósítása. A pedagógusok nagyobb hangsúlyt fektetnének a nevelésre, emelnék a neveltségi szintet, növelnék a nevelés hatékonyságát, s több nevelési elvet érvényesítenének. Olyan gyermekeket szeretnének formálni, akik képesek a kulturált viselkedésre, helyes viselkedési szokásaik vannak, rendszeresen tanulnak, jól nevelt, szabályokat ismerők és betartók, s megállják helyüket az életben. A nevelési területek közül az alábbiakra helyeznének hangsúlyt az egész napos nevelömunkában: erkölcsi, munkára, fegyelemre és értékkövetésre nevelés. A tanulói személyiség komplex fejlesztését valósítanák meg annak érdekében, hogy a lehető legtöbbet tudják ,kihozni” a gyermekekből.

A nevelés hangsúlyos feladataként szerepelt a közösségfejlesztés is. A pedagógusok célja, hogy az egész napos nevelés során közösséggé formálják az osztályt, erősítsék az összetartozás érzését, a „közösségi szellem”-et, az iskolához való kötődést, olyan közösséget formáljanak, amelyben a tanulók jól érzik magukat együtt egész nap. Többen megjelölték azt is, hogy mindezt közös feladatok, élmények, hagyományok teremtésével, az együttélési szabályok kialakításával, a közösségi játékokban való aktív részvétellel, az együttmüködés, az együttdolgozás, az alkalmazkodás kialakításával és a társas kapcsolatok harmonikusabbá tételével kívánják megvalósítani. Mindezekhez szeretnék a gyermekek képességeit, személyiségét alaposabban megismerni.

Jó kapcsolatot szeretnének kialakítani föként a tanulókkal, de sokan megemlítik a kollégákat és a szülőket is. A tanulókkal szeretnének közvetlenebb, személyesebb, őszintébb kapcsolatot létesíteni, annak érdekében, hogy második otthonukként szeressék az iskolát. Céljuk a jó tanári csapatmunka, a hatékony együttmüködés, a szorosabb kapcsolat az osztályban tanító kollégákkal. Szeretnének jó kontaktust létesíteni a szülőkkel, intenzívebbé tenni a kommunikációt napi találkozásokkal, hogy a nevelő hatásokat ezzel is fokozni tudják.

A szokásrendszer formálása, az alapvető szociális viselkedés, az illemszabályok, a helyes életmód, a rendszeres napirend kialakítása, a megfelelő időbeosztás fontosságának felismertetése és a felelősi rendszer müködtetése fontos cél, annak érdekében, hogy a gyermekek tanítási és tanórán kívüli tevékenysége összefüggő rendszert alkosson és végső soron rendszert vigyen a tanulók életébe. 
A kérdőíveken megfogalmazták a nevelök, hogy szeretnék otthonossá tenni az iskolát, családias, toleráns, szeretetteljes, biztonságos légkört, nyugodt körülményeket, jó hangulatú foglalkozásokat kívánnak biztosítani, amelyben mind a tanulók, mind a pedagógusok jól érzik magukat.

A szabadidős tevékenységek szervezése kapcsán a legfőbb cél a változatosság biztosítása volt. Emellett szeretnék megtanítani a gyermekeket az együtt játszás örömére, szeretnék a sportot mindennapossá tenni, sok játékot biztosítani, „homo ludens”-eket nevelni. A játékot megjelenítenék a képességek fejlesztésében is, s közben a kulturált játék szabályait és igényét is megtanítanák a gyermekeknek. Egyenletes nap terhelést szeretnének biztosítani tanulóik részére a tanulás-pihenés megfelelő arányával, a gyermekek napi terhelésének egyenletes elosztásával és a jobb időbeosztással.

A kérdőív végén megkértük a kutatásban részt vevőket, írják le véleményüket az egész napos nevelés (egész napos iskola) általánossá tételével kapcsolatban!

A megkérdezettek 5,93\%-ának nem volt véleménye vagy nem akarta azt közölni. A többiek válaszainak elemzésekor alapvetően három csoportot lehetett elkülöníteni:

\begin{tabular}{|l|c|}
\hline Teljesen elutasítja az egész napos iskolát & $12,28 \%$ \\
\hline Részben egyetért az egész napos iskolával & $45,33 \%$ \\
\hline Teljesen egyetért az egész napos iskola bevezetésével & $36,44 \%$ \\
\hline
\end{tabular}

Azokban a válaszokban, amelyekben a pedagógusok teljesen elutasították az egész napos iskola bevezetését, a legnagyobb arányban azt nehezményezték, hogy az egész napos iskola jelentősen lerövidíti azt az időt, amit a gyermekek a családjukkal tölthetnének. „Az egész napos nevelés nem ad lehetöséget azoknak a szülöknek, akik otthon szeretnék a gyermekeikkel tartalmasan eltölteni a délutánokat."

A pedagógusok a szülők felé is fogalmaztak meg kritikákat. Véleményük szerint a gyermekek egy része azért van délután az iskolában, hogy ne otthon okozzanak gondot. Úgy érzik, az egész napos iskolának csak akkor lenne értelme, ha a szülők értéknek tekintenék a tanulást.

A pedagógusok túlterheltsége is gyakori hivatkozási alap: „A pedagógus számára nagyon kimeritö, és senki sem tudná néhány hétnél tovább csinálni”; „, A pedagógusok eddig is egész nap az iskolában voltak, mikor töltödjenek fel?"

Az elutasítók véleményében az is megjelent, hogy a tanulók napjának ily módon való megszervezésével a gyermekek körüli összes probléma az iskolára helyeződik át. Nagy gondnak érzik a tárgyi feltételek hiányát is. Néhány véleményadó pedig kifejezetten a pedagógusok ellen való intézkedésként éli meg: „Újabb megalázó lépésnek tartom a nevelőkkel szemben.”

A részben egyetértők csoportja bizonyult a legnagyobb számúnak. Itt a legnagyobb arányban azok a megállapítások szerepeltek, amelyek a választás 
lehetőségének megtartása mellett szóltak, bár az érvelések különbözőek. Legtöbben az eltérő családi háttér és a tanulók képességeiben, igényeiben meglévő különbségek miatt képviselik a választhatóságot. Tapasztalataikra hivatkozva a megkérdezett nevelők úgy vélik, hogy sok olyan család van, ahol az édesanya frissen fözött ebéddel várja otthon csemetéjét és ebéd közben mindjárt megbeszélik az élményeket, bánatokat. Az anyuka ráér gyermekével beszélgetni, leckét írni és segíteni, ha szükséges. A dolgozó szülők számára azonban nagy segítség, mivel nekik hét közben nincs elég idejük a gyermek tanulásával megfelelőképpen foglalkozni, így örömmel veszik, hogy az iskola átvállalja ezt a feladatot. „Fontosnak tartom, hogy legyen szülöi igény is arra, hogy a gyermekek egész nap az iskolában legyenek. Úgy gondolom, ezt nem lehet rákényszeriteni a családokra, viszont ahol szükségesnek tartják, ott nagyon hasznos lehet." „Véleményem szerint választható lehetöségként lenne célszerü felajánlani. Azoknak a szülöknek, akiknek olyan a munkabeosztása, hogy nem tudják megoldani a gyermek elhelyezését, megoldást jelenthetne. Teljes mértékben viszont az iskola nem veheti át a család szerepét. Ha a kisgyerek kora reggeltöl késő délutánig az iskolában tartózkodik, nagyon kevés idő jut a családnak arra, hogy együtt töltse az időt." „Nem feltétlenül szerencsés azon gyermekek számára kötelezövé tenni, akik megfelelö, segítö, támogató családi háttérrel rendelkeznek, és a tanitási órák után szerető család várja öket."

Sokak véleménye szerint az egész napos iskola csak és kizárólag az alsó évfolyamokon eredményes. Az indokok szerint ebben a korban lehet kialakítani a tanulók különböző szokásait, sok segítséget igényelnek a tanulásban, a kreativitás kibontakoztatásában. Ebben az életkorban jobban hallgatnak tanítójukra, s szakkörökre is többen járnak, mint a felsőbb évfolyamokon. Alsó tagozaton többet lehet a gyermekekkel beszélgetni és játszani, felzárkóztatásra és tehetséggondozásra is több idő jut. Felső tagozaton azért nem gondolják müködőképesnek, mert úgy vélik, ötödik osztálytól kezdődően a tanulók már nehezen türik a kötöttségeket. Általában otthon, egyedül jobban szeretnek tanulni. Többen érveltek azzal, hogy kamaszkorban csökken az érdeklődés a tanulás iránt, ezért a délutáni órákban már nagyon nehéz a felsős tanulókat motiválni az iskolában. „Alsó tagozaton teljes mértékben egyetértek az egész napos neveléssel. A gyerekek minél idősebbek, annál nehezebb egész nap az iskolában tartani öket. Legalábbis színvonalas keretek között. Én köztes megoldást javasolnék. Felsö tagozaton meghagynám a napközi vagy a tanulószoba bevált formáit azoknak a tanulóknak, akiknek erre szükségük van, mert a szülök dolgoznak, elfoglaltak vagy nem tudnak segíteni a tanulásban. Ezen kívül színvonalas, tartalmas szakköri foglalkozásokkal csábítanám be az idősebb tanulókat az iskolába."

A választhatóság igénye a tanulók különbözőségéből fakadóan is megjelenik. A megkérdezettek véleménye szerint a hátrányos helyzetü gyermekek fejlődését nagyban elősegíti az egész napos nevelés, hiszen az iskola olykor a gyermekmegőrzési, illetve gondozási feladatokon túl „,családpótló” szerepet is betölt azáltal, hogy segíti a tanulókat egyéni problémáik megoldásában. Az egyre jobban szétforgácsolódó családok gyermekeinek az egész napos iskolai napirend 
egy biztos, állandó kapaszkodót nyújt, jobban eligazodnak az őket körülvevő világban, hamarabb válnak szabálykövetővé, tudják, hogy kik ők és hol van az ő kis helyük a világban. Ugyanakkor úgy érzik, a bevezetést rugalmasan kell kezelni, mert az egész napos iskola nem akadályozhatja meg a gyermekek egyéb délutáni elfoglaltságait: szakkörök, különórák, zeneiskola, sport, melyek egy része ráadásul az iskolán kívül szervezett. „A tehetséges tanulók különóráit gátolná. A szegényebb tanulóknak jó, mert a meleg étkezés biztosított.” „Hátrányos helyzetüeknek jó, tehetségeseket hátráltatja a különórákban.” „Akik sportolnak vagy egyéb különórákra járnak, kifejlödik az a képességük, hogy gyorsan, csak a tanulásra koncentrálva végezzék a munkájukat, irják meg a házi feladatot, így van lehetöségük az egyéb vállalt feladataikra is. Ezt a kötelezö egész napos iskola nem biztos, hogy lehetövé tenné."

A pedagógusok véleménye szerint nem minden iskola alkalmas erre a feladatra. Akkor tud az egész napos nevelés jól müködni, ha a nevelök szívesen, hozzáértéssel végzik a munkájukat, ugyanis a tanulók egész napos foglalkoztatása erőt próbáló feladat. A jó müködés további feltételeiként az eszköz-, a tanszerellátottság és a megfelelő tantermek biztosítását nevezték meg. Úgy vélik, jelenleg nem áll rendelkezésre megfelelő számú és nagyságú tornaterem, a szakkörök, külön foglalkozások anyagszükségletére pedig nincs anyagi fedezet. Sokan a magas osztálylétszámokban látják a megvalósítás legfőbb akadályát, ami a tanulók személyiségében, érdeklődésében és képességeiben meglévő különbözőségeket figyelembe vevő sokszínü tevékenységrendszer megszervezését nagyban gátolja. „Iskolánk alapvetö feltételei hiányosak: nincs megfelelö iskolaudvar, nincs tornaterem, nincs zárható, lekerített saját területe a tagintézménynek (magánterülettel együtt van egy kis tér a diákok részére). Megfelelö feltételek mellett a tantestület szakmai szempontból jó célkitüzésnek tartja az egész napos oktatást.” „Az egész napos nevelés maximum 15-20 gyerekkel lenne ideális. Így valószínüleg egyénileg vagy kis csoportokban is lehetne a gyerekekkel foglalkozni. Emellett a szabadidös programokra is lehetne anyagilag tervezni. Nem éppen olcsó egy színházi előadás, egy kiállitás- vagy egy könyvtárlátogatás a falusi gyerekeknek (útiköltség, belépö stb.).”

Az egész napos iskolai foglalkoztatás általánossá tételével részben egyetértő pedagógusok körében találkoztunk olyan véleményekkel, melyek szerint a megvalósítás fö akadálya a családok anyagi helyzete. Meglátásuk szerint egyre több szülö nem tudja fizetni gyermeke iskolai étkezését. Ingyenes étkeztetésre nem jogosult a gyermek, de a család anyagi körülményei nem teszik lehetővé az ebédbefizetést. A tanulók iskolai étkeztetésből való kikerülésének okát több megkérdezett az iskolai közétkeztetés alacsony színvonalában is látja. ,, Sok szülö azért nem íratja be alsó tagozaton iskolaotthonba a gyerekét, mert nem tudja fizetni az étkezési dijat.” „Nem tenném kötelezövé, csak választhatóvá. A szülöknek a napi 3 étkezés igen drága.” „Az egész napos nevelést akkor lehet kötelezövé tenni, ha biztosítják az ingyenes étkezést a tanulók számára. Emiatt sok tanuló nem igényelheti iskolánkban jelenleg sem a tanulószobát." 
Azok, akik teljesen egyetértettek az egész napos iskola bevezetésével, szinte minden esetben saját pozitív tapasztalataikra hivatkoztak. „Sok éves tapasztalatommal azt állithatom, hogy az egész napos iskolarendszer általános bevezetésének tervét támogatom.” „A mi iskolánkban mindig is egész napos nevelés folyt, alsó tagozaton napközi otthon, felsö tagozaton tanulószobai foglalkozás segítette a tanulók felkészülését. A továbbiakban is szeretnénk eszerint végezni munkánkat."

A támogató vélemények szerint a gyermekek az egész napos nevelés keretében sokkal hatékonyabban sajátíthatják el a tananyagot, sokkal szervezettebben, hatékonyabban tölthetik el szabadidejüket. A tanulók mind egymással, mind a pedagógusokkal jobb, bensőségesebb kapcsolatot tudnak kiépíteni, s ennek köszönhetően tanulmányi eredményük és személyiségük is pozitív irányba változik.

A kutatásban részt vevő pedagógusok beszámoltak arról is, hogy településeiken éppen az egész napos nevelés miatt, a szülök is szívesen választják intézményeiket, mivel az iskola délután a gyermekek számára sok lehetőséget biztosít felzárkóztató, tehetséggondozó programok megvalósítására. Többféle szakkört, hangszertanulást, néptáncfoglalkozást, sportolási lehetőséget tudnak biztosítani. Úgy érzik, a tanulóknak szükségük van az egész napjukat kitöltő értelmes elfoglaltságokra, mert a szülőknek egyre kevesebb idejük van arra, hogy gyermekeik tanulásának folyamatával foglalkozzanak, illetve, hogy biztosítsák számukra a szabadidő helyes eltöltését. „,Támogatom és javaslom a bevezetését, hiszen ez a munkaforma ad csak lehetöséget az iskola által nyújtott szolgáltatások legteljesebb körü igénybe vételére, jó a gyermeknek és jó a pedagógusnak egyaránt, s a jól szervezett iskolaotthonos munkaforma a szülöknek is nagy segitséget ad." „Naponta elkészitik a házi feladatot. A hétvégét teljesen szabaddá lehet tenni. Az iskolaotthon leveszi a szülök válláról a tanulási gondot.” „,Felsö tagozaton jó megoldás az esélyteremtö oktatás megvalósításához. Nemcsak a tananyag elsajátítását kell biztosítani, hanem a tehetséggondozást, felzárkóztatást és az egyénre szabott törödést is."

Az egész napos iskola bevezetését támogató tanárok, tanítók jelentős része kiemelte, hogy ebben a foglalkoztatási formában a gyermekek több helyzetben és jobban megismerhetők, ezáltal az egyénre szabott oktatási és nevelési folyamat eredményesebb lehet. A tanulóközösség minél több időt tölt együtt, a közösségi szabályokat annál jobban elsajátítják, így az osztály hamarabb összekovácsolódik. A gyermekek a társadalmi, közösségi viselkedés normáit ugyanis leghatékonyabban a társak között, közösségben tanulják meg. A tanulók legjobban a játékokon keresztül fejleszthetők. Erre csak az egész napos iskola ad időt, lehetőséget. A tananyag mélyebb, jobb elsajátításán túl az egymás közötti kommunikáció, az egymás iránti tolerancia fejlesztésére ebben a munkaformában tud leginkább figyelni a pedagógus. „Az egész napos nevelés során több oldalról, jobban megismerhetjük tanulóinkat. Fejlesztésük jobban megoldható. Közösségük jobban alakitható." 
A nevelés szempontjából jónak tartják a pedagógusok, hogy az egész napos iskolában minden kolléga taníthat is, és a délutáni elfoglaltságokból is kiveheti a részét. A tanulók megismerhetők tanulás, játék és szabadidős tevékenység közben egyaránt, s ezáltal körültekintőbb differenciálásra, egyénre szabott technikák tanítására, egész napos tanári segítségnyújtásra, következetesebb nevelésre nyílik lehetőség. „Mindkét tanitó látja a gyermeket az önálló tanulás folyamatában, megfigyelheti szabadidöben társai között, így a nevelés is lényegesen hatékonyabb lehet.” „Azt gondolom, ha az együtt dolgozó pedagógusok jól tudnak együttmüködni, mindannyian szívesen végzik a munkájukat, ez a munkaforma mindenképpen a gyerekek hasznát szolgálja. Én már nem szivesen dolgoznék a hagyományos iskolai rendszerben."

\section{A kutatás tapasztalatainak összegzése}

Az egész napos nevelés pedagógiai hasznossága a pedagógusok véleményének tükrében meglehetősen változatos képet mutat. Az egész napjukat az iskolában töltő gyermekek egészséges és harmonikus testi, lelki és szellemi fejlödéséhez nélkülözhetetlenek az olyan pedagógusszemélyiségek, akik hivatásuk gyakorlását igaz szeretettel és odaadással élik meg. A megkérdezett nevelők háromnegyedénél szerepel munkájuk belső indíttatásának indokaként a gyermekek szeretete, a tanítás szeretete, a szakmai elkötelezettség, a neveltekkel együtt töltött több idő és a tanulók alaposabb megismerésének lehetősége. Szinte ugyanilyen arányban azért szeretik munkájukat, mert jobban megismerhetik tanítványaikat, nevelni tudják őket. Örömet lelnek munkájukban, mert örömet találnak a gyermekekkel való foglalkozásban, hivatástudat vezérli öket. Mindebböl következően nem okozott meglepetést, hogy a kutatásban részt vevők több mint 40\%-a a gyermekekkel végzett munkájában legfontosabb célként nevelési feladatok megvalósítását nevezte meg: jó kapcsolatot igyekeznek kialakítani a neveltekkel, illetve arra törekednek, hogy még alaposabban megismerhessék őket.

Ugyanakkor a vizsgálatban részt vevő nevelök közel 40\%-a semmiféle belső indítékot sem írt munkavégzésével kapcsolatban, csupán külső körülményeket! A megkérdezettek harmada indokolta az egész napos nevelőmunkában való részvételét a munkahelyén vagy saját életében bekövetkezett, szükségszerüséget előidéző helyzet kialakulásával: munkahelyét csak úgy tudta megtartani, ha belevág, vagy éppen ezt az állást találta, munkára volt szüksége, tehát elfogadta a felkínált munkakört.

$\mathrm{Az}$ eredmények alapján elmondható, hogy bár a legtöbb örömöt tanítványaikban találják meg, a legtöbb bosszúságot, szomorúságot is ők okozzák nekik. A nevelök ugyanis a munkájukat elkedvetlenítő okok megfogalmazásakor a legnagyobb arányban olyan dolgokat neveztek meg, amelyek a neveltekkel kapcsolatosak. Fáradékonyaknak, közömböseknek, agresszívaknek, egyre gyengébb képességüeknek, nehezen motiválhatóknak találják őket. Úgy érzik, a gyermekek egyre több problémával küszködnek, neveltségi szintjük alacsony - és nem érték számukra a tanulás. 
Az iskolai nevelőmunka hatékonyságának növeléséhez elkerülhetetlen a szülőkkel, a családdal való kapcsolat minőségének emelése. A megkérdezettek közel 10\%-a szerint munkahelyükön a szülői igények hívták életre az egész napos nevelés valamely szervezeti formáját. Az intézmény a szülők elfoglaltságára való tekintettel terjesztette ki a nevelőmunkát a délutáni időszakra is. A kutatásban részt vevő nevelök, ugyanilyen arányban, azért szeretik munkájukat, mert jobb kapcsolatot tudnak kialakítani a szülőkkel, az egész napos nevelés során napi kontaktusba tudnak velük kerülni.

Ugyanakkor a nevelőmunkában elkedvetlenedésre okot adó jelenségek második nagy csoportja is a szülökre vonatkozik. A pedagógusok nehezményezik, hogy a szülök nem partnerek a nevelésben, nem becsülik eléggé a tanárok munkáját, nincsenek tisztában gyermekeik kompetenciáinak határaival, passzívak, érdektelenek, minden feladatot az iskolára hárítanának, mert nincs elég idejük csemetéikre. Az összes megkérdezett fele gondolja csupán, hogy az egész napos nevelés során a szülőkkel való kapcsolattartás intenzívebbé tehető. Ennek oka abban lelhetö fel, hogy a pedagógusok jelentős része közömbösnek, az iskola dolgai iránt nehezen mozdíthatónak találja a szülőket.

Az egész napos nevelés során kiemelten fontos, hogy az egy osztályban tanítók jó szakmai és emberi kapcsolatban álljanak egymással, hiszen a délelőtti és délutáni tevékenységek csak így alakíthatók egységes pedagógiai rendszerré.

A kollégákkal való együttműködés a megkérdezettek számára belső motivációt nyújt az egész napos nevelésben való részvételhez. Az iskolaotthonban tanítók szeretnek párban dolgozni, úgy érzik, így hatékonyabbak, van lehetőség a tapasztalatok cseréjére, s jobban lehet segíteni egymást. Feladatvégzésükre vonatkozó célkitüzéseik között is szerepel a kollégákkal való kontaktus minőségének javítása. Az összes megkérdezett háromnegyede gondolja hatékonyabbnak az egy osztályban tanítók együttmüködését az egész napos nevelés keretei között!

Az összegzésben meg kell említenünk azokat a véleményeket is, amelyeket az alsó tagozatos pedagógusok fejeztek ki a nevelötestület többi tagjával kapcsolatban. A napközi otthonban tanítók sérelmezték ugyanis, hogy kollégáik gyakran lenézően viszonyulnak munkájukhoz, a szemükben ök gyakran „csak” napközisek. Vizsgálatunk eredményei azt mutatják, hogy az egész napos nevelőmunkában részt vevő pedagógusok véleményének tükrében a szülők és a nevelőtársak körében egyaránt érzékelhető a délutáni nevelőmunka lekicsinylése. A tapasztalatok alapján kijelenthető, hogy a napközis nevelömunka fontosságának felismertetése még mindig egy előttünk álló feladat.

Az egész napos iskola általánossá tételével kapcsolatban a vizsgálatban részt vevő s jelenleg is az egész napos nevelés valamely szervezeti formájában dolgozó pedagógusok köre alapvetően egyetértését fejezte ki, hiszen az összes megkérdezett háromnegyede ért vele egyet részben vagy teljes mértékben.

A kutatás eredményeinek összegzéseképpen elmondható, hogy a pedagógusok leginkább a gyermekek megismerésének lehetőségét, az egy osztályban tanítók együttmüködését és a tehetségekkel való foglalkozást tartják 
leginkább megvalósíthatónak az egész napos nevelés során. Az egész napos nevelés szervezeti formái közül az iskolaotthonban dolgozók aránya volt a legmagasabb. A kutatásban részt vevők öt legfontosabb célkitűzése a tanulásban való segítségnyújtás, a felzárkóztatás, a közösség fejlesztése, a képességek fejlesztése és a tehetséggondozás volt.

\section{Az egész napos iskola bevezetésére vonatkozó következtetések}

A kutatásban részt vevő öt megye általános iskolai tanárai, tanítói tapasztalat által formált véleményének tükrében jól kirajzolódik, hogy az egész napra szervezett iskolai nevelés csak ott müködik hatékonyan, ahol a pedagógiai hatásokat teljes, összefüggö, egységesebb rendszerré tudják formálni az intézmények. Az eredmények azt mutatják, hogy pusztán a különböző szervezeti formák müködtetésével nem lehet kiaknázni az ezekben rejlö összes lehetőséget, ha a nevelötestület tagjai nem látják pontosan egymás munkáját, ha nem érzik azok helyét, szerepét és jelentőségét az iskola egész szervezetének müködésében, a közösen kitűzött s a pedagógiai programban rögzített célok elérésében, ha nem tudnak egymás munkájára megfelelően alapozni.

Ahhoz, hogy az iskolák az egész napos nevelést teljes pedagógiai rendszerré tudják formálni, elsősorban intézményük sajátosságait kell áttekinteniük, alapvetően az alábbi négy területen:

1. nevelőtestület

2. tanulóközösségek

3. tárgyi feltételek

4. környezeti adottságok.

A nevelőtestület tagjainak képzettsége nyilvánvalóan meghatározza a tantárgyfelosztást, a tanítási órákon kívüli foglalkozások tartását és egyéb, a kutatásban is feltárt funkciók kiosztását. Mindezen túl fontosnak látszik, hogy a nevelötestület tagjai ismerjék egymás érdeklődési területeit, egy-egy szakmai téma iránti elköteleződéseit. Ezáltal még inkább egymás partnereivé tudnak válni olyan feladatok végrehajtásában, amelyek az egész napos iskolai foglalkoztatásban megvalósíthatók. Ezek a közösen végzett munkák egyrészt közelebb hozhatják egymáshoz azokat a kollégákat, akik szakjukból fakadóan egyébként nem találnának azonos területet az együttdolgozásra. Így viszont betekintést nyerhetnek egymás munkájába, feladatköreibe, ami segíthet az elöítéletek megszüntetésében. Másrészt a tanulók részére színesebb programok szervezhetők, amelyek élvezetesebbek a gyermekek számára, ha nemcsak a szaktanár vezeti vagy vesz részt azon, hanem egy másik nevelőjük is. Továbbá a közös érdeklödés alapján szervezett programoknak óriási motivációs hatásuk van a résztvevők szempontjából, így nevelési hatásuk is sokkal nagyobb, mint az ötlettelenül, a szokás alapján szervezetteké.

A vizsgálat tapasztalatai is bizonyították, hogy a pedagógusok együttműködésében nagyon sok lehetőség rejlik. A szakmai fejlődés szempontjából kiemelten fontos, hogy sokat tudnak egymástól tanulni, biztatást, elismerést kaphatnak, s ez által egymás szakmai önbecsülését is pozitívan 
befolyásolhatják. A folyamatos konzultációk, esetmegbeszélések, a közös gondolkodás pedig az iskolában folyó munka szakmai színvonalát emelhetik.

Mint ahogyan azt a kutatásban részt vevők is megfogalmazták, az egész napot átfogó nevelőmunka megvalósításához nélkülözhetetlen a pedagógusok elkötelezettsége. Ennek hiányában ez a munka nagyon fárasztó és kimerítő lehet. A tanulók egész napjának tervezése és szervezése nagyfokú rugalmasságot és kreativitást igényel a nevelőktől. A hatékonyság növelése érdekében szükség van folyamatos szakmai megújulásukra. A gyermekek motivációs szintjének fenntartása gazdag pedagógiai módszer- és eszköztár működtetését igényli. Mindemellett türelmes nevelöi attitüdre is nagy szükség van, hiszen a nevelés eredményei nem tükröződnek feltétlenül azonnal, ezért a tanulók változásába vetett bizalom is elengedhetetlen feltétele e munkának.

A tanulóközösségek összetételének, és azokban minden tanuló képességének, érdeklődésének, szociális helyzetének ismerete szintén alapvető fontosságú a nevelési hatásrendszerek kidolgozásához. Az általunk megkérdezett pedagógusok véleménye is alátámasztja, hogy az iskolának egyre több feladatot kell átvennie a családoktól. Kulturális programok biztosítása, a tanulók érzelmi, sőt - sajnálatos módon - gyakran testi szükségleteinek kielégítése és a kulturált viselkedési szokások kialakítása egyaránt feladatává vált. Mindemellett meg kell küzdenie a média és az internetes kommunikáció tanulók értékrendjére gyakorolt negatív hatásaival is.

Az osztályközösségekben, a tanulók személyiségében és családi körülményeiben tapasztalható különbségek minden iskolát más-más kihívások elé állítanak. Az egész napra szervezett pedagógiai hatásrendszer alkalmas a tanulók igényeihez, szükségleteihez igazított sajátos válaszok megadására.

Az egész napos foglalkoztatás optimális formáinak kialakítását, a nevelési szempontból nagy hatékonyságot biztosító különböző programok szervezését természetesen nagymértékben befolyásolják az intézmény tárgyi és környezeti feltételei. Az iskolai terek száma, mérete, berendezése és eszközellátottsága, valamint az intézmény környezeti fekvése, elhelyezkedése a településen, továbbá az iskolán kívül szervezett programok elérhetősége egyaránt hatással van a pedagógiai hatásrendszer szervezésére. Azonban az iskolák, s bennük a délutáni foglalkozások, nem először kerültek nehéz anyagi helyzetbe a történelem során. $\mathrm{Az}$ egész napos nevelés rendszerét ma nem újjáépíteni kell, mint a második világháború után, hanem újjászervezni. Több mint hatvan évvel ezelőtt az összefogás segített. Ez sokat javíthat a mai helyzeten is. Ha az iskolai nevelőmunkában érintettek köréből mindenki hozzátesz valamit a fejlesztéshez, a lehetőségek határai egyre jobban kitolódnak. A szülők hozzájárulása egy-egy otthon már megunt vagy feleslegessé vált játékkal a délutáni szabadidő értelmes eltöltéséhez, nem terheli meg anyagilag a családokat. Ugyanígy csupán a szabadidejükből kell áldozniuk az udvar rendbetétele vagy az osztályterem barátságosabbá, otthonosabbá változtatása érdekében. Az intézményvezetők, az osztályfőnökök és a nevelőtestület minden tagja részéről az intézményben folyó programok megvalósításának menedzseléséhez még kreatívabb és 
professzionálisabb hozzáállásra van szükség. Mindehhez, természetesen, elengedhetetlen különböző pályázati lehetőségek és központi források biztosítása is.

Összefogással jelentős lépéseket tehetünk az iskolák müködési feltételeinek optimalizálásához és ezáltal az egész napos iskola hatékonyságának növeléséhez, melynek egy jól kidolgozott, de minden egyes intézmény sajátosságaihoz igazodó, egységes hatásrendszerrel müködő megvalósítása óriási lehetőség az iskolák számára, hogy a rájuk háruló megnövekedett feladatokat sikeresen meg tudják oldani.

\section{Jegyzetek}

A 2011. évi CXC. törvény a nemzeti köznevelésről.

Báthory Zoltán - Falus Iván (szerk. 1997): Pedagógiai Lexikon I. Keraban Könyvkiadó.

Bognár Mária (szerk. 1984): A tanulás irányítása. Az egész napos nevelés útján. Továbbképzési füzetek 2, OPI.

Eperjessy Gézáné (1981): Mire jó az egész napos nevelés? Tankönyvkiadó, Budapest.

Füle Sándor (2004): Napközi otthoni neveléstan. OKKER.

Füle Sándor (é. n.): A magyarországi iskolai napközi otthonok vázlatos története; $A z$ iskolai napközi otthoni nevelömunka fejlödése Magyarországon. Előadásjegyzetek (kézirat).

Nagy Sándor (szerk. 1976): Pedagógiai Lexikon I. Akadémiai Kiadó, Budapest.

Nagy Sándor (szerk. 1978): Pedagógiai Lexikon III. Akadémiai Kiadó, Budapest.

Szabadkai Simonné (1968): A hazai egész napos iskola pedagógiai kérdései. In: Pedagógiai Szemle, 9. sz. 